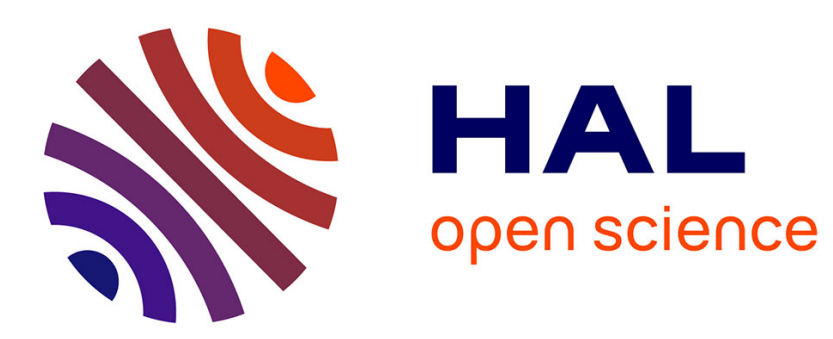

\title{
A shared suppletive pattern in the pronominal systems of Chang Naga and Southern Qiang

\author{
Guillaume Jacques
}

\section{To cite this version:}

Guillaume Jacques. A shared suppletive pattern in the pronominal systems of Chang Naga and Southern Qiang. Cahiers de linguistique - Asie Orientale, 2007, 36 (1), pp.61-78. halshs-00200873v2

\section{HAL Id: halshs-00200873 \\ https://shs.hal.science/halshs-00200873v2}

Submitted on 9 Nov 2008

HAL is a multi-disciplinary open access archive for the deposit and dissemination of scientific research documents, whether they are published or not. The documents may come from teaching and research institutions in France or abroad, or from public or private research centers.
L'archive ouverte pluridisciplinaire HAL, est destinée au dépôt et à la diffusion de documents scientifiques de niveau recherche, publiés ou non, émanant des établissements d'enseignement et de recherche français ou étrangers, des laboratoires publics ou privés. 
A shared suppletive pattern in the pronominal systems of Chang Naga and Southern Qiang. ${ }^{1}$

Guillaume Jacques, Université Paris 5 René Descartes - CRLAO

Cahiers de linguistique - Asie orientale, 2007, 36.1:61-78.

Abstract: This article shows the existence of a similar irregular alternation in pronominal the morphology of Chang Naga and Southern Qiang, two distantly related Sino-Tibetan languages. This pattern is argued to be the trace from an older case marking system. On the basis of this hypothesis, a new analysis of pronominal systems in various languages of the family is presented.

Keywords : Sino-Tibetan, Naga, Qiang, morphology, pronouns, suppletive pattern.

Abstract: Cet article montre l'existence d'une alternance irrégulière similaire dans la morphologie des pronoms du chang naga et du qiang méridional, deux langues sino-tibétaines lointainement apparentées l'une avec l'autre. Cette alternation est analysée comme une rétention et comme la trace d'un système de cas en sino-tibétain, et sur la base de cette hypothèse, nous présentons une nouvelle analyse des systèmes pronominaux de diverses langues de cette famille.

Mots-clés : Sino-tibétain, naga, qiang, morphologie, pronom, supplétisme.

${ }^{1}$ I thank Katia Chirkova, Boyd Michailovsky, Alexis Michaud, Laurent Sagart and two anonymous reviewers for insightful comments on earlier versions of this paper, as well as Asüngba for sharing with me his knowledge of Chang Naga. All errors are mine. 
Pronouns have played an important role in the history of proto-Sino-Tibetan ${ }^{2}$ reconstruction. Thus, the Tibetan first person pronoun $n g a$ with its Chinese equivalent 吾 wú were among the first proposed cognates by Abel Rémusat as early as 1820. In the development of Sino-Tibetan historical linguistics, the study of pronouns has had far-reaching consequences in at least two domains.

First, pronouns are central to the ongoing discussion on the verbal agreement system present in some branches of Sino-Tibetan. Agreement suffixes in Rgyalrong, Kiranti, Chepang and other languages have been variously seen as forms recently grammaticalized from pronouns (LaPolla 1992) ${ }^{3}$ or as retentions from a putative proto-Sino-Tibetan agreement system (van Driem 1993).

Second, pronouns have proven crucial for our understanding of the subgrouping of Sino-Tibetan. For example, pronominal paradigms have been used as basis for new subgroupings within the family such as 'Rongic' (Thurgood 1985). Alternatively, Sagart $(1996,1999)$ claimed that the Tibetan first person pronoun $n g a$ and similar forms in other languages were not cognates as previously assumed, but loanwords from Chinese.

In connection to the latter argument, the present article advances a new hypothesis concerning the pronominal system of Sino-Tibetan, based on the analysis of a suppletive pattern observed in the Chang Naga language spoken in Nagaland (Northeastern India) and the Southern Qiang language spoken in rNgaba (Aba) District (Sichuan province, China).

\section{CHANG NAGA}

$\mathrm{Chang}^{4}$ is a little studied Northern Naga language spoken in the Tuensang district of Nagaland. The Northern Naga subgroup of Sino-Tibetan comprises languages such as Konyak, Phom, Wancho, Tangsa, Nocte and Khiamungan. The main sources of data on this language are Hutton (1987 [1929]) and Erdican (2003).

Northern Naga languages are argued to be related to Jinghpo and Bodo-Garo languages within the so-called 'Sal' subgroup (Burling 2003), rather than to the various Naga languages of the south; 'Naga' is mostly an ethnic term, and has little linguistic relevance.

Chang has a mostly agglutinative case marking system, but as in many languages with this type of system, such as Turkish, the declension of the pronouns is irregular. It exhibits a complex suppletive pattern, as shown in Table $1^{5}$ :

\footnotetext{
${ }^{2}$ Since no evidence has been adduced of common innovation to all Sino-Tibetan languages besides Chinese, it is prudent given the state of knowledge on the family not to talk of a 'Tibeto-Burman' subgroup within Sino-Tibetan. Our use of 'Sino-Tibetan' is equivalent to Driem (2005)'s understanding of the term 'Tibeto-Burman'.

${ }^{3}$ In all these languages, most verbal agreement markers are nearly identical with independent pronouns.

4 The local name of the language is tçán $\eta \dot{\gamma} y$.

5 These data have been collected during summer 2007 by the author in Shillong and Guwahati. The paradigms recorded by Hutton (1987 [1929]: 20) are almost identical to those presented in this paper. Chang Naga is transcribed in IPA, and the tone marks follow the africanist conventions: à (low tone), á (high tone) and â (falling tone).
} 


\begin{tabular}{|c|c|c|c|c|c|}
\hline & $1 \mathrm{sg}$. & 1du.incl. & 1du.excl. & 1pl.incl. & 1pl.excl. \\
\hline Absolutive & yò & śr tì & ḱ́ sì & sर̂n & $\mathrm{k} \hat{\gamma} \mathrm{n}$ \\
\hline Ergative & ฤદ̀i & sq́ tjễ & k'́r sjế & sर̂́n عì & 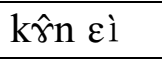 \\
\hline Genitive & jèi pú & sर́ tjêi pù & k'́ sjêi pù & sર́n દî pù & kŕn દî pù \\
\hline Ablative & k'́r kà & śr tî kà & k'́ sî kà & ŝ̂n kà & k̂̂rn kà \\
\hline Allative & k’̀ lá & ś́ tî là & k'́ sî là & ş̂n là & k̂́n là \\
\hline \multirow[t]{2}{*}{ Dative } & $\mathrm{k}$ '́ tò & sर́ tî tò & ḱr sî tò & ŝ̂n tò & k̂̂n tò \\
\hline & $2 \mathrm{sg}$. & $2 \mathrm{du}$. & $2 \mathrm{pl}$ & & \\
\hline Absolutive & nó & kà sî & kân & & \\
\hline Ergative & jî̀ & kà sjêci & kân عì & & \\
\hline Genitive & kài pú & kà sjêi pù̀ & kán عî pù & & \\
\hline Ablative & kà kâ & kà sì kâ & kân kà & & \\
\hline Allative & kà lá & kà sì lâ & kân là & & \\
\hline Dative & kà tô & kà sì tô & kân tò & & \\
\hline
\end{tabular}

Table 1: Pronoun declension in Chang Naga

If we put aside case markers (- $\varepsilon i,-\varepsilon i p u,-k a,-l a$ and $-t o$ ) and number suffixes (-si "dual" and $-n$ "plural") we are left with the bare pronoun stems. In the first person, there are three stems $\eta \grave{\partial}, \eta \grave{\varepsilon} i, k \gamma$ - to which the inclusive form "you and me" $s \gamma$ - can be added, and in the second person, there are four distinct stems: nó, nî, kài- and ka-.

However, this analysis can be carried further. The ergative forms $\eta \grave{\varepsilon} i$ and $n \hat{i}$ are without doubt the result of a fusion of the Absolutive stems nò and nó with the Ergative suffix $-\varepsilon i$, although the fusion must have occurred at an early stage of proto-Chang, as the forms $\eta \grave{\varepsilon} i$ and $j \hat{i}$ are irregular from the point of view of synchronic morphology: *ywéi and *nwéi would be expected instead. Similarly, the form kài- is best analyzed as the fusion of the stem $k a$ - and the first syllable of the Genitive suffix - $\varepsilon i p u$.

Therefore, it appears that the pronominal paradigms of Chang Naga can be reduced to a simpler system with two stems for each person, the first stem appearing in the Absolutive and the Ergative singular, and the second stem in the Ablative, Allative and Dative singular, as well as in all the dual and plural forms.

\begin{tabular}{|l|l|l|}
\hline & $1^{\text {st }}$ person & $2^{\text {nd }}$ person \\
\hline $1^{\text {st }}$ stem (Absolutive, Ergative) & yò & nó \\
\hline $2^{\text {nd }}$ stem (Ablative, Allative, Dative) & $\mathrm{k} \gamma-$ & ka- \\
\hline
\end{tabular}

Table 2: Analysis of the Chang pronominal system.

The Genitive forms cannot be placed in this table, as the first person singular yèipú has the stem 1, whereas the second person kàipú has stem 2. The reason for this discrepancy is unknown.

The bare stem 2 forms $k \gamma$ - and $k a$ - also occur as possessive prefixes ("my" and "your" respectively) in Chang, but their use is restricted to kinship terms, for instance $k \grave{\text { - } 6 o ́ w ~(1 s g-d a u g h t e r) ~ " m y ~ d a u g h t e r " . ~}$

In French (1983)'s proto-Northern Naga, reconstructions are provided for first 
series pronouns: *ya ${ }^{\mathrm{A}}$ (French 1983:264, 295), *nan (1983:272, 389). However, it should be noted that both Chang pronouns are irregular, as according to French's laws of correspondence, Chang first person should be *now, and second person should be

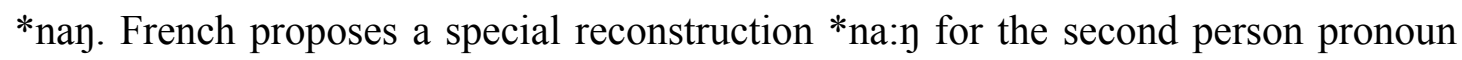
in Chang with a lengthened vowel to explain the attested form (proto-Northern Naga *-a:y regularly corresponds to Chang -o). The irregularity of the first person is probably due to analogical leveling with the second person.

Other Northern Naga languages either only preserved the first series of pronouns, such as Phom ( $1^{\text {st }}$ person $\eta \Lambda y^{33}, 2^{\text {nd }}$ person nuu $y^{33}$, Burling and Phom 1998$)$, or mix the two series, such as Wancho $\left(1^{\text {st }}\right.$ person $k u^{44}, 2^{\text {nd }}$ person $n a \eta^{44}$, Burling and Wangsu 1998 ).

\section{SOUTHERN QIANG}

The Qiang dialects are spoken in the rNgaba (Aba) Prefecture of Northern Sichuan. Together with Rgyalrong, Muya, Queyu, Zhaba, Pumi, Shixing, Ersu, Guiqiong and the extinct Tangut language, they are considered to be part of the Qiangic subgroup of the Sino-Tibetan family. In contrast with other Qiangic languages, Qiang is relatively well described and even some reconstructions of proto-Qiang have been proposed (Evans 2001). Only southern Qiang dialects spoken in Wenchuan and Lixian Counties appear to preserve archaic flexions, while they have disappeared in Northern Qiang. The following analysis is based on the Southern Qiang dialect of 桃坪 Táopíng, as described by Liu Guangkun (1998) ${ }^{6}$. The pronominal declension of the Táopíng dialect is as follows:

\begin{tabular}{|l|l|l|}
\hline & $1^{\text {st }}$ person & $2^{\text {nd }}$ person \\
\hline Nominative / Agentive & $\mathrm{ya}^{55}$ & $\mathrm{no}^{55}$ \\
\hline Genitive & $\mathrm{qo}^{55}$ & $\mathrm{ko}^{55}$ \\
\hline Accusative & $\mathrm{qa}^{55}$ & $\mathrm{ku}^{55}$ \\
\hline
\end{tabular}

Table 3: Declension of pronouns in Southern Qiang. (Liu 1998: 247)

The genitive forms $q o^{55}$ and $k o^{55}$ are derived from the accusative $q a^{55}$ and $k u \vartheta^{55}$ by changing the rime to $-\mathrm{o}$. A similar change also occurs with the interrogative pronoun «who » $\left(s 1^{55} \rightarrow s o^{55}\right)$ and the third person pronoun $\left(m \partial^{33} \rightarrow m o^{33}\right)$. This change is due to the fusion of the pronouns with a postposition $z o^{33}$ (Liu 1998: 252). The pronouns of Northern Qiang are identical with Southern Qiang accusative forms, save for the loss of tonal contrasts: qa and kuə (Liu 1998: 134).

Therefore, there are only two sets of pronominal stems in Qiang:

\begin{tabular}{|l|l|l|}
\hline & $1^{\text {st }}$ person & $2^{\text {nd }}$ person \\
\hline
\end{tabular}

\footnotetext{
${ }^{6}$ The first description of the Southern Qiang pronominal system appeared in Wen (1941).
} 


\begin{tabular}{|l|l|l|}
\hline stem I & ya $^{55} \leftarrow{ }^{*}$ ya- \#499 & no $^{55} \leftarrow{ }^{*}$ no- $\leftarrow{ }^{*}$ nay $\# 987^{7}$ \\
\hline stem II & qa $^{55} \leftarrow{ }^{*}$ qa- \#498 & kuə $^{55} \leftarrow{ }^{*}$ kuə- \#989 \\
\hline
\end{tabular}

Table 4: Two pronominal stems in Southern Qiang (Evans' 2001's Proto-Southern Qiang reconstructions are preceded by an asterisk and followed by the cognate set number)

In Huang (2004)'s description the closely related Púxī 蒲溪 dialect, the dual and plural forms lack stem alternations. First person non-singular exclusive and second person pronouns are based on the singular second stems qa- and kue-, a situation strikingly similar to Chang Naga:

\begin{tabular}{|l|l|l|l|l|l|l|l|c|}
\hline & 1sg. & 1du.incl. & 1du.excl. & 1pl.incl. & 1pl.excl. & 2sg. & 2du. & 3 pl. \\
\hline I & ya & tsy-n & qa-n & tsy-la & qa-la & no & kue-n & kue-la \\
\cline { 1 - 1 } II & qa & & & & & & & \\
\hline
\end{tabular}

Table 5: Puxi Qiang pronominal system (Huang 2004: 54).

Recently, Huang and Evans (2006) have proposed a different analysis of the Qiang pronominal system, arguing that the stem alternation was not determined by syntactic roles, but by pragmatics. According to their analysis, stem I marks topic, and stem II non-topic. Here are some of their examples:
(1) na thala se $e^{t}$
1sg:TOP 3sg beat: 1
I am beating him/her.

(2) thala qa se

3sg 1sg:NTOP beat:3

$\mathrm{S} / \mathrm{he}$ is beating me.

(3) pa thala-i se

$1 \mathrm{sg}$ :TOP 3sg-AGT beat:3

I am being beaten by him/her.

The patient is first person singular in both sentences (2) and (3), but in the second example, the pronoun is topicalized, and stem I pa appears instead of stem II qa. If stem II truly marked accusative case, we would expect qa to be present in both sentences. This analysis seems preferable to the former descriptions in terms of syntactic cases.

Qiang appears to be the only Qiangic language which preserves two series of pronouns. The first series is the only one attested in other Qiangic languages. For example, the first person pronoun in Rgyalrong can be reconstructed as *ya (Japhug ąo, Eastern Rgyalrong pa) and the second as *nay (Japhug nъъo, Eastern Rgyalrong no, see Jacques 2004).

\section{COMPARISON}

The similarity between the pronominal systems of Chang and Qiang is obvious

\footnotetext{
7 According to Evans (2001: 161-2), the pronoun $n o^{55}$ belongs to the group of examples where Taoping Qiang $-\mathrm{O}$ comes from proto-Qiang *-ay.
} 
when one compares the data in Table 2 and Table 4, especially when the protoNorthern-Naga and the proto-Qiang reconstructions are taken into account. It should be noted that the alternation between the two series of pronouns cannot be attributed in either language to the trace of an old phonological alternation, as an alternation between a velar stop and a dental nasal in the case of the second person is not documented as a morphological process anywhere in the Sino-Tibetan family. This must therefore be a suppletive pattern.

Sagart (1996) first noticed the similarity between the first person pronouns in the two languages. In his analysis, the opposition between $\eta \grave{o}$ and $k r$-in Chang on the one hand and that between $\eta a^{55}$ and $q a^{55}$ in Qiang on the other hand, was that between a free form appearing in non-suffixed cases and a bound form appearing with suffixes or prefixed to nouns. Sagart furthermore argued that the former forms ( $y o$ in Chang and $\eta a^{55}$ in Qiang) as well as their cognates in other Sino-Tibetan languages (Tibetan $n g a$, Burmese $n g a^{2}$ etc.) all were loaned from Chinese 吾 *nya. The latter forms $(k \gamma$ - in Chang and $q a^{55}$ in Qiang), on the other hand, were the actual native first person pronouns of these languages. Sagart's argument is the following. The form 吾 *yya is not attested in the earliest Chinese texts, where only 余 *la is used as a first person singular pronoun. According to him, the paradigm of pronouns in Western Zhou Chinese was as follows (the reconstructions have been changed to the more recent Baxter-Sagart system):

\begin{tabular}{|l|l|l|}
\hline & $1^{\text {st }}$ person & $2^{\text {nd }}$ person \\
\hline singular & 余 *la & 汝 *na? \\
\hline plural & 我 *nyaj & 爾 *naj? \\
\hline
\end{tabular}

Table 6: Personal pronouns in the Western Zhou period (Sagart 1999: 142)

The pronoun 吾 *yya, written with the phonetic 魚 *ya in early Bronze inscriptions, only appears in the Eastern Zhou period and gradually replaces 余 *la. Sagart explains this late replacement as a case of proportional analogy: the initial *1 was replaced by * $y$ to make the paradigm more regular. Therefore, Chinese 吾 *yya is an innovation and did not exist in proto-Chinese.

In Sagart's analysis, since this development is internal to Chinese, the presence of similar forms in other Sino-Tibetan languages can only be explained as the result of borrowing. Moreover, the fact that the borrowed pronouns are the free forms, whereas the inherited ones are the bound forms in the systems of both languages is one more piece of evidence in favor of this theory: the inherited forms, existing in the language for a longer time than the borrowed ones, have become more grammaticalized, while the borrowed forms are still independent words. However, Sagart's borrowing hypothesis is questionable for three reasons.

First, in Qiang the first and second person singular verbal agreement suffixes (respectively $-a$ and $-n$ ) are derived from the first series pronouns * ya and *nay (LaPolla and Huang 2003: 142), not from * qa and *kuə. In the second person, the $-n$ suffix can directly be linked to *nay. In the first person, it might seem at first glance that - a could be derived either from *ya or *qa. However, if from *qa, the suffix 
would have experienced consonnant weakening and changed to ${ }^{*}-\mathrm{x}$ (Liu 1998: 74): *ya is the only possible origin of this suffix. Therefore, it is false to assume that *ya is the 'free form' and *qa the 'bound' one.

Second, the forms cognate to proto-Qiang *ya and *nay are widely found in ST languages of Northeastern India and Nepal where Chinese influence is unlikely to have been present even indirectly.

Third, even granted that the first person pronoun of the first series could be analyzed as a borrowing from Chinese, this would be impossible for the second person pronoun, as Chinese 汝 *na? has no final nasal, unlike proto-Qiang *nay and cognate forms in other languages (Burmese $n a n g^{2}$ etc).

Therefore, we believe it is safer to assume as is commonly done that these pronouns are cognate to Chinese, rather than borrowings. Since the borrowing hypothesis can be discarded, another explanation will be needed to explain the two series of pronouns.

The data presented in Table 2 and Table 5Table 4 above show that Qiang and Chang share a similar suppletive pattern not only in the first person pronouns as was noticed by Sagart, but also in the second person. The similarity of the pronominal systems of Qiang and Chang is not merely formal, as the grammatical value of the opposition between stem I and stem II is similar in both languages. First, stem alternation is limited to singular pronouns: in the dual and plural forms, only stem II appears ( $\mathrm{kr}-\mathrm{ka}$ - in Chang, qa-/kue- in Qiang). Second, stem I is used for the only argument of an intransitive verb, and for the agent of a transitive verb (i.e. the prototypical subject of an accusative language). Third, stem II appears with almost all forms that have postpositions (except the Chang 1sg genitive $\eta \dot{\varepsilon} i p u \hat{u}$ ).

At this stage of our research, is too early to reconstruct the value of this opposition in the proto-language, as it could have been either a syntactically conditioned case system or a pragmatically determined topic/comment marking. However, this strongly suggests, contra Thurgood (1985), that the first person pronoun *qa is not the common innovation of a putative 'Rongic' subgroup, but retention from proto-Sino-Tibetan.

The hypothesis of a common retention is not provable until the historical phonology and morphology of these languages is better understood. For it to be true, several specific sound changes should have happened. For example, Qiang kuə would come from an earlier form with an open vowel like Chang $k a-$. The origin of the distinction between velar and uvular present in Qiang, but absent in Chang, should also be explained.

If these hypotheses are not disproven eventually, this would be a strong piece of evidence for the existence of a case system in the common ancestor of Chang and Qiang. Since these two languages are very remote both geographically and phylogenetically, their nearest common ancestor might be proto-Sino-Tibetan, which would mean that we ought to reconstruct these two series of pronouns in the proto-language of the entire family. Using the idea that the two series of pronouns possibly go back to proto-Sino-Tibetan, it becomes possible to explain most attested pronominal systems in Sino-Tibetan languages. We shall examine three major systems: 
Kiranti, Burmese and Kuki-Chin.

Kiranti languages are the only group of Sino-Tibetan other than Chang and Qiang where both pronominal series are attested, though not with the same function. Since verbal and pronominal morphology in Kiranti language is extremely complex, we shall limit our discussion to five forms in several languages, which should be enough to make our point: the first and second person singular pronouns, the second person singular possessive prefix, the first person agreement suffix and the first person singular agent / second person singular patient portmanteau suffix. The Hayu data are from Michailovsky (1988: 124), Limbu from Michailovsky (2002) and Chamling from Ebert (2003: 535); Bahing data are kindly provided by B. Michailovsky.

\begin{tabular}{|l|l|l|l|l|}
\hline & Hayu & Bahing & Chamling & Limbu \\
\hline 1 sg pronoun & gu & gu & kaya & inga \\
\hline 2 sg pronoun & gon & gø & khana & khen $\varepsilon$ \\
\hline 2 sg possessive prefix & uy- & i- & kap- & ke- \\
\hline 1 sg intr. suffix & -no & -na & -uya & $-\mathrm{Na} /$-ay \\
\hline 1 sg agent, 2sg patient suffix & -no & -na & -na & -n $\varepsilon$ \\
\hline
\end{tabular}

Table 7: Pronouns and verbal agreement suffixes in some Kiranti languages.

From the data in Table 7, it appears that verbal suffixes are derived from the first series pronouns, while the independent pronouns seem to contain the second series pronouns ( $k a-$ / $k h a$ - in Chamling, gu, gon in Hayu, gu / gø in Bahing etc).

The second person singular possessive prefix also is possibly linked to the second series pronoun in several of these languages. In Limbu, a synonymous prefix keserves as second person marker in verbal agreement. It is impossible to analyze the Kiranti systems in more detail without a clear understanding of phonological correspondances, but in any case there can be no doubt that the two series of pronouns have left traces in those languages. How exactly the two series of pronouns that we propose to reconstruct for proto-Sino-Tibetan developed into the system of pronouns and agreement affixes attested in Kiranti languages is left for future investigations. It is interesting to notice that agreement suffixes in Kiranti and in all other Sino-Tibetan languages without any exception are based on stem I pronouns, never on stem II.

The "Burmese" pronominal system (first person $y a^{2}$, second person $n a \eta^{2}$ ) is the most widespread one attested in the Sino-Tibetan family. It exists in Lolo-Burmese, Rgyalrong, Bai, Tani, Trong, Jinghpo and Kham. It is also possibly found in

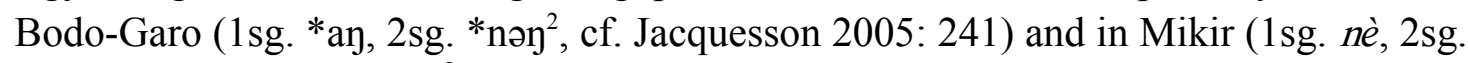
nàng, Grüssner 1978: 81) ${ }^{8}$. It is the only system reconstructed in Matisoff (2003). The Chinese set of pronouns is likely to have derived from it, though the precise details are still unclear (in particular, the change from 余 *la to 吾 *yya between Western and Eastern Zhou is left unexplained). The Tangut pronominal system (Kepping 1985: 43) also can be derived from the "Burmese" one by supposing a leveling analogy

\footnotetext{
${ }^{8}$ In Mikir, the uvular nasal phoneme /ng/ never appears in the onset of a syllable, and original *n probably changed to other nasals in that position: 'Ansonsten scheint ursprünglich anlautendes $/ \mathrm{ng} / \mathrm{entweder} \mathrm{zu} / \mathrm{n} /$ oder zu /m/ umgewandelt worden zu sein' (Grüssner 1978: 13). Therefore, it is possible that 1sg. nè comes from *yè.
} 
(Jacques 2006: 131) ${ }^{9}$.

The system attested in all these languages simply corresponds to the first series of pronouns of the Qiang / Chang system (proto-Qiang *ya and *nay): the second series disappeared altogether.

Kuki-Chin languages have a mixed system that combines the two series in the same way as Wancho (see the last paragraph of the first section). The first person pronouns are from the second series (cognate to proto-Qiang * qa), whereas the second person pronouns come from the first series (proto-Qiang *nay). Here are some data from the Chin language Hakha Lai:

\begin{tabular}{|l|c|c|l|l|}
\hline \multirow{2}{*}{} & \multicolumn{2}{|c|}{ independent } & \multicolumn{2}{c|}{ possessive } \\
\cline { 2 - 5 } & singular & plural & singular & plural \\
\hline first person & key-ma? & kan-ma? & ka- & ka-n- \\
\hline second person & nay-ma? & nan-ma? & na- & na-n- \\
\hline
\end{tabular}

Table 8: Hakha Lai pronominal system (Peterson: 2003)

The pronominal systems of other languages of the family also seem to integrate elements of one series or the other, but without a clear understanding of the historical phonology of each individual language, the comparisons are shaky. Systems potentially similar to the Kuki-Chin one are found in Sulong $\left(1 \mathrm{sg}\right.$. $g o h^{55}, 2 \mathrm{sg} . n a^{55}$, cf. Li 2004: 118) and Geman (1sg. $k i^{53}, 2$ sg. $j o^{53}$, Li 2002: 115). In Lepcha, the first person pronoun plural and dual kányi and káyú contain an element ká- possibly cognate to the second series pronom (Qiang *qa), whereas the origin of the singular pronoun go is more difficult to determine. Finally, some languages of the Sino-Tibetan family have pronominal systems that do not seem to be relatable to the ones presented above. For instance, in Newar, first and second person singular pronouns (respectively $j i$ and cho) cannot be compared either to the first series or to the second series of pronouns.

More precise comparisons between Sino-Tibetan languages with respect to their pronominal systems will only become possible when their historical phonology is better understood.

\section{CONCLUSION}

Previous studies in comparative Sino-Tibetan morphology have mainly focused on productive patterns and paradigms, and neglected the investigation of irregular morphology. However, comparative grammar, as is well known from the work of Indo-Europeanists, should be based on irregular paradigms, not on productive ones. As more ST languages become described, it is hoped that other examples of common irregularities in the verbal and nominal morphological systems of these languages will be discovered.

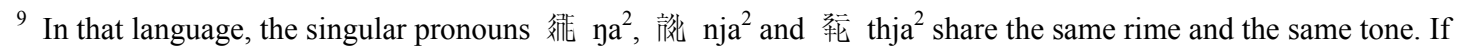
from the *na / *nan system, the Tangut form of the first and second persons ought to be **nji and **njij. It is therefore necessary either to suppose analogy with the rime of the third person pronoun or a fusion of the three pronouns with a morpheme having the rime $-\mathrm{ja}$.
} 
BURLING Robbins (2003). Northeastern India, in THURGOOD Graham and Randy J. LAPOLLA (eds.). Sino-Tibetan Languages, London: Routledge, pp. 169-191. BURLING Robbins and Amon PHOM (1998). Phom phonology and Word List, Linguistics of the Tibeto-Burman Area (Berkeley), 21.2, pp. 13-42.

BURLING Robbins and Mangkai WANGSU (1998). Wancho phonology and Word List, Linguistics of the Tibeto-Burman Area (Berkeley), 21.2, pp. 43-71.

VAN DRIEM Georges (1993). The Proto-Tibeto-Burman verbal agreement system, $B S O A S$ (London), 61.2, 292-334.

VAN DRIEM Georges (2005). Tibeto-Burman vs. Indo-Chinese, in SAGART L., R. BLENCH and A. SANCHEZ-MAZAS (eds.). The Peopling of East Asia, London: RoutledgeCurzon, pp.81-106.

EBERT Karen (2003). 'Chamling', in THURGOOD Graham and Randy J. LAPOLLA (eds.). Sino-Tibetan Languages, London: Routledge, pp. 169-191.

ERDICAN Achilla Imlong (2003). Chang-English, English-Chang Dictionary. New Delhi: Prestige Books.

EVANS, Jonathan (2001). Introduction to Qiang Phonology and Lexicon: Synchrony and Diachrony. Tokyo: ILCAA.

FRENCH, Walter (1983). Northern Naga: a Tibeto-Burman Mesolanguage. PhD dissertation, City University of New York.

GRÜSSNER, Karl-Heinz (1978). Arleng Alam, Die Sprache der Mikir. Wiesbaden: F. Steiner Verlag.

HUANG Chenglong 黄成龙 (2004). A Reference Grammar of the Puxi Variety of Qiang, PhD Dissertation. Hong Kong: City University of Hong Kong.

HUANG Chenglong 黄成龙 and Jonathan P. EVANS (2006). Qiang Split Pronoun Systems, paper presented at the 14th IACL \& 10th IsCLL, Academia Sinica, Taipei; May 27.

JACQUES Guillaume (2004). Phonologie et morphologie du japhug (Rgyalrong), thèse de doctorat, Paris 7.

JACQUES Guillaume (2006). Essai de comparaison des rimes du tangoute et $\mathrm{du}$ Rgyalrong, in BECKWITH Christopher (ed.). Medieval Tibeto-Burman Languages II, Leiden: Brill, pp.121-152.

JACQUESSON François (2005). Le Deuri, langue Tibéto-birmane d'Assam, Paris: Peeters.

KEPPING Ksenia (1985). Tangutskij jazyk - morfologija, Moscow: Nauka.

LAPOLLA Randy J. (1992). On the dating and nature of verb agreement in Tibeto-burman, BSOAS (London) 55.2:298-315.

LAPOLLA Randy J. and HUANG Chenglong (2003). A Grammar of Qiang with annotated texts and glossary, Berlin: Mouton de Gruyter.

LI Daqin 李大勤 (2002). 格曼语研究 Gemanyu yanjiu [Research on the Geman language]. Beijing: Minzu chubanshe

LI Daqin 李大勤 (2004). 苏龙语研究 Sulongyu yanjiu [Research on the Sulong 
language]. Beijing: Minzu chubanshe

LIU Guangkun 刘光坤 (1998). 麻窝㒸语研究 Mawo Qiangyu yanjiu [Research on the Mawo Qiang language]. Chengdu: Sichuan minzu chubanshe.

HUTTON J.H. (revised and edited by Satkari Mukhopadhyay) (1987). [1929] Chang Language, Grammar and Vocabulary of the Language of the Chang Naga Tribe, Delhi : Gian Publishing House.

MATISOFF James (2003). A. Handbook of Proto-Tibeto-Burman, Berkeley: University of California Press

MICHAILOVSKY Boyd (1988). La langue hayu, Paris: Editions du CNRS.

MICHAILOVSKY Boyd. (2002). Limbu-English dictionary of the Mewa Khola Dialect with English-Limbu Index, Kathmandu: Mandala Book Point.

PETERSON David. (2003). Hakha lai, in THURGOOD Graham and Randy J. LAPOLLA (eds.). Sino-Tibetan Languages, London: Routledge, pp. 409-426.

RÉMUSAT Abel (1820). Recherches sur les langues tartares. Paris: Imprimerie royale.

SAGART Laurent (1996). OC 吾 *ya : inherited or innovated ?, Paper presented at the $29^{\text {th }}$ ICSTLL, October 12-13, Noordwijkerhout, the Netherlands.

SAGART Laurent (1999). The Roots of Old Chinese. Amsterdam: Benjamins.

THURGOOD Graham (1985). Pronouns, verb agreement systems, and the subgrouping of Tibeto-Burman, in THURGOOD Graham, James A. MATISOFF and David BRADLEY (eds.). Linguistics of the Tibeto-Burman Area: The State of the Art, Pacific Linguistics C-87. Canberra: The Australian National University, pp. 376-400.

WEN Yu 聞宥 (1941). 川西㒸语之初步分析 Chuanxi qiangyu zhi chubu fenxi [a preliminary analysis of Qiang dialects of Western Sichuan], Studia Serica 2:38-71. 